УДК 631.53:633.112.9

(C) 2018

Цехмейструк М. Г., кандидат сільськогосподарських наук, Шеляків В. О., науковий співробітник

Інститут рослинництва ім. В. Я. Юр'єва НААНУ

\author{
Шевніков М. Я., доктор сільськогосподарських наук, \\ Литвиненко О. С., аспірант \\ Полтавська державна аграрна академія
}

\title{
ВПЛИВ СТРОКІВ СІВБИ НА УРОЖАЙНІСТЬ СОРТІВ СОЇ
}

\section{Рецензент - доктор сільськогосподарських наук, професор П. В. Писаренко}

Результати дослідів підтверджують можливість отримання стабільних врожаїв за рахунок підбору строку сівби та фону мінерального живлення. У середньому за 2002-2005 рр. у сорту Романтика відмічена чітка тенденція збільшення врожайності від ранніх до пізніх строків незалежно від фонів живлення (від 1,73 m/2а до 2,08 m/2а в середньому за 4 роки). У сортів Мрія та Аметист на фоні без добрив має місие така ж тенденція, тоді як на фоні застосування добрив найбільш оптимальними строками були більи ранні (ІІІ декада квітня і I декада травня), ніж пізні. Вищий рівень продуктивності сої за 20062010 рр. було отримано за раннього (22.04) строку сівби - 1,82 m/2a, а найгірші показники отримано за пізнього (21.05) строку сівби, де врожайність була в межах 1,67 m/2a. В розрізі сортів: кращчі результати, за більшості строків сівби, окрім пізніх, було отримано у випадку вирощування сорту Романтика, який забезпечив отримання 1,84-1,87 m/2а насіння. 3а пізніх строків сівби третій (06.05), четвертий (14.05) та п'ятий (21.05) вищий рівень продуктивності було отримано за вирощування сорту Аннушка - 1,72$1,85 \mathrm{~m} / \mathrm{2a}$.

Ключові слова: соя, урожайність, погодні умови, строки сівби, фони живлення.

Постановка проблеми. У зв'язку з поширенням нових сортів сої виникає питання з'ясування елементів технології вирощування, що мають забезпечити високу іiі продуктивність. Особливе значення мають строки сівби насіння сої. Соя, як світлолюбна культура, формує високий урожай лише за оптимальних для конкретного сорту площі живлення і густоті рослин, забезпеченні вологою і поживними речовинами, але основна вимога - найкраще освітлення листкової поверхні. Як світлолюбна культура, вона забезпечує високий урожай лише за оптимальної для конкретного сорту площі живлення і густоті рослин, а також у разі відповідної структури посіву.

Із впровадженням у виробництво адаптованих ранньостиглих сортів сої виникла проблема забезпечення гарантованого щорічного формуван- ня якісного врожаю насіння до настання несприятливих для збирання умов осіннього періоду. Подальше поширення сої в умовах нестійкого зволоження Лівобережного Лісостепу стримується недостатньо обгрунтованою зональною технологією її вирощування, особливо за ранньої сівби, де тепло є обмежуючим фактором. Потребують вивчення процеси формування врожаю i якості насіння сої за різних строків сівби. У зв'язку з цим особливого значення набуває раціональне використання ресурсів тепла у ранньовесняний період за рахунок ранніх строків сівби. Ці фактори і $€$ підставою для вивчення строків сівби в умовах нестійкого зволоження Лівобережного Лісостепу України.

Аналіз останніх досліджень і публікацій, у яких започатковано розв'язання проблеми. Зерно сої $є$ широко розповсюдженим харчовим $\mathrm{i}$ кормовим продуктом поряд із цінним білком, у його склад входить олія з низьким вмістом холестерину [1] та високим вмістом (56-60,3 \%) цінної лінолевої жирної кислоти [2]. Реалізація біологічного потенціалу сучасних сортів сої в конкретних умовах вирощування можлива лише за повної відповідності технології вирощування вимогам культури до факторів життя. Тому в основу підбору сортів повинен бути покладений екологічний принцип, який характеризується використанням закону взаємозв'язку рослинних організмів із навколишнім середовищем [3, 4]. Слід зазначити, що за стрімкого зростання посівних площ сої рівень її урожайності залишається майже незмінним і становить у середньому по Україні від 0,10 до 1,40 т/га. Цей показник не відповідає сучасним вимогам $[5,6]$. Зростання в останні роки чисельності аномальних погодних явищ висуває вимоги, які важко поєднати в одному сорті. У зв'язку з цим одним з основних завдань, яке стоїть нині перед селекціонерами та технологами, є виведення і впровадження у виробництво сортів із високим адаптивним потенціалом та рівнем продуктивності [7]. 


\section{СІЛЬСЬКЕ ГОСПОДАРСТВО. РОСЛИННИЦТВО}

Більшість розробок нині спрямовані на підвищення верхньої межі урожайності сорту за сприятливих умов вирощування i недооцінюється роль лімітуючих і сукупної взаємодії агроекологічних факторів на підвищення нижньої межі продуктивності за несприятливого поєднання факторів довкілля. Для організації стабільного виробництва насіння сої в зонах із лімітуючими факторами довкілля необхідна система різнопланових сортів, здатних за різних погодних умов і на різних фонах забезпечити отримання стабільних врожаїв, що досягається завдяки їх нормі реакції на умови вирощування $[8,9]$.

Збільшення виробництва сої в Україні в найближчій перспективі можливе лише за умови підвищення продуктивності цієї культури на основі ефективного розміщення і раціонального використання сортових ресурсів та впровадження у виробництво конкурентоспроможних, з високим рівнем окупності енергії, адаптованих до умов середовища технологій [10-12].

У мобілізації потенціалу продуктивності нових сортів сої важливим є застосування специфічних для них особливостей вирощування 3 урахуванням біологічних потреб. При цьому слід виходити із необхідності ресурсозбереження та забезпечення рослин факторами життя [13, 14].

Різні сорти сої реагують на довжину дня порізному [15-20]. Встановлено, що серед ранньостиглих сортів сої існують значні відмінності по чутливості до світлового періоду [19]. Автори вважають, що сорти з незначною реакцією на довжину дня належать до нейтральних, але для більшості 3 них сприятлива тривалість дня становить 13-15 годин. А. О. Бабич, С. І. Колісник та інші [20] вважають, що зона нестійкого зволоження Дніпропетровської, Донецької, Запорізької, Кіровоградської, Луганської, Миколаївської, Одеської, Харківської областей за тепловими та світловими ресурсами $є$ придатною для вирощування ранньостиглих та скоростиглих сортів сої. Обираючи строк сівби сої, слід враховувати рівень температурного режиму та вологість посівного шару грунту. Рослини раннього строку сівби (третя декада квітня) мали довший період вегетації порівняно з рослинами пізнього строку сівби. У випадку недостатньої забезпеченості вологою грунту та підвищеної температури повітря вегетаційний період вкорочувався на 7-12 днів [22, 23].

Методика проведення досліджень. Основні польові дослідження проводилися в період 20042013 рр. в лабораторії рослинництва та сортовивчення Інституту рослинництва ім. В. Я. Юр'єва НААН України. Грунт - глибокий слабовилугуваний чорнозем із зернистою структурою. Він характеризується такими агрохімічними показниками: вміст гумусу (за Тюріним) $-5,8 \%$; $\mathrm{pH}-$ 5,8 ; гідролітична кислотність - 3,29 мг/екв. на 100 г грунту. Запаси поживних речовин на контролі без добрив: азот - 132 мг/кг, фосфор - 104 мг/кг, калій - 128 мг/кг; на фоні із застосуванням мінеральних добрив $\left(\mathrm{N}_{30} \mathrm{P}_{30} \mathrm{~K}_{30}\right)$ : азот - 140 мг/кг, фосфор - 177 мг/кг, калій - 172 мг/кг грунту. В умовах зони проведення досліджень основними лімітуючими факторами $є$ кількість опадів та температурний режим у період вегетації сільськогосподарських культур і олійних у тому числі. За роки досліджень погодні умови в період вегетації рослин були досить контрастними, що дало змогу повною мірою оцінити сорти та гібриди олійних культур. У середньому за роки досліджень відхилення за середньодобовою температурою становить плюс $1,3^{\circ} \mathrm{C}$. У той же час існує значна різниця за місяцями і роками. Так, відмічається значне потепління періоду серпеньлистопад, на $0,9-3,1{ }^{\circ} \mathrm{C}$, а також більш прохолодні, на $0,2{ }^{\circ} \mathrm{C}$, квітень і червень. Березень тепліший на $0,9^{\circ} \mathrm{C}$, а травень - на $0,5^{\circ} \mathrm{C}$. Окрім середньодобових температур велике значення для росту та розвитку рослин має сума ефективних (понад $10^{\circ} \mathrm{C}$ ) температур за певні періоди. В середньому за період досліджень сума ефективних температур становила $1496,8^{\circ} \mathrm{C}$, що на $290,8^{\circ} \mathrm{C}$, або $24,1 \%$ вище середньо багаторічного показника. Відмічено зростання даного показника по всіх місяцях від 5,9 до $101,1{ }^{\circ} \mathrm{C}$. Так, у середньому по досліду за роки досліджень сума опадів, у порівнянні з багаторічними значеннями, зросла на 34,4 мм. Відмічена значна строкатість у їх надходженні залежно від року та місяців. Окрім розрахунків відхилень були розраховані лінійні регресії по середньодобових температурах за період весняно-літньої вегетації. Розрахунки свідчать про постійне і стабільне підвищення середньодобових температур по всіх місяцях. У той же час воно незначне у квітні і різко підвищується в літні місяці, особливо в серпні.

Результати дослідження. Вивчення впливу строків сівби на урожайність сої проводили у 2002-2005 pp. на сортах Аметист, Мрія та Романтика, у 2006-2015 pp. - на сортах Аннушка, Романтика та Скеля, а в 2016-2017 pp. - на сортах Білявка, Спритна та Мальвіна. Перший строк сівби сої припадає на третю декаду квітня, другий строк - на першу декаду травня, третій строк - на другу декаду травня. За результатами багаторічних досліджень IP ім. В. Я. Юр'єва НААН встановлено, що строки сівби по-різному впливали на урожайність сортів сої. 
СІЛЬСЬКЕ ГОСПОДАРСТВО. РОСЛИННИЦТВО

Урожайність сортів сої залежно від строків сівби, $m / 2 a$

\begin{tabular}{|c|c|c|c|c|c|c|}
\hline \multirow[b]{2}{*}{ Сорти } & \multicolumn{2}{|c|}{ 1-й строк } & \multicolumn{2}{|c|}{ 2-й строк } & \multicolumn{2}{|c|}{ 3-й строк } \\
\hline & без добрив & $\begin{array}{c}\text { гній + } \\
\mathrm{N}_{60} \mathrm{P}_{60} \mathrm{~K}_{60}\end{array}$ & $\begin{array}{c}\text { без } \\
\text { добрив }\end{array}$ & $\begin{array}{c}\text { гній + } \\
\mathrm{N}_{60} \mathrm{P}_{60} \mathrm{~K}_{60}\end{array}$ & $\begin{array}{c}\text { без } \\
\text { добрив }\end{array}$ & $\begin{array}{c}\text { гній }+ \\
\mathrm{N}_{60} \mathrm{P}_{60} \mathrm{~K}_{60}\end{array}$ \\
\hline \multicolumn{7}{|c|}{ середне за 2002-2005 pp. } \\
\hline Аметист & 1,90 & 2,26 & 2,02 & 2,22 & 2,06 & 2,13 \\
\hline Мрія & 2,00 & 2,24 & 2,10 & 2,29 & 2,29 & 2,17 \\
\hline Романтика & 1,73 & 1,95 & 1,88 & 2,09 & 2,06 & 2,08 \\
\hline Середнє & 1,88 & 2,15 & 2,00 & 2,20 & 2,14 & 2,13 \\
\hline \multicolumn{7}{|c|}{ середне за 2006-2010 рр. } \\
\hline Аннушка & 1,55 & 1,75 & 1,65 & 1,91 & 1,65 & 1,93 \\
\hline Романтика & 1,75 & 1,85 & 1,77 & 1,85 & 1,70 & 1,73 \\
\hline Скеля & 1,64 & 1,74 & 1,55 & 1,62 & 1,53 & 1,58 \\
\hline Середнє & 1,65 & 1,78 & 1,66 & 1,79 & 1,63 & 1,74 \\
\hline
\end{tabular}

Відмічена різна реакція сортів сої на строки сівби. Результати дослідів підтверджують можливість отримання стабільних врожаїв за рахунок підбору строку сівби та фону мінерального живлення. Вони також свідчать про те, що основним фактором, який визначає рівень урожайності сої, є погодні умови в критичні фази росту для конкретного сорту (див. табл.).

Так, у середньому за 2002-2005 pp. у сорту Романтика відмічена чітка тенденція збільшення врожайності від ранніх до пізніх строків незалежно від фонів живлення (від 1,73 т/га до 2,08 т/га в середньому за 4 роки). У сортів Мрія та Аметист на фоні без добрив проявляється така ж тенденція, тоді як на фоні застосування добрив найбільш оптимальними строками були більш ранні (III декада квітня і I декада травня) ніж пізні.

У період з 2006 по 2010 рр. вивчали вплив на урожайність різних за групами стиглості сортів (Аннушка, Романтика та Скеля) сої 5 строків посіву.

За результатами досліджень, вищий рівень продуктивності культури було отримано за раннього (22.04) строку сівби - 1,82 т/га, а найгірші показники отримано за пізнього (21.05) строку сівби, де врожайність була в межах 1,67 т/га. В розрізі сортів: кращі результати, за більшості строків, окрім пізніх, було отримано під час вирощування сорту Романтика, який забезпечив отримання 1,84-1,87 т/га насіння. За пізніх строків - третій (06.05), четвертий (14.05) та п’ятий (21.05) вищий рівень продуктивності було отримано у випадку вирощування сорту Аннушка - 1,72-1,85 т/га.

Спостерігається певна сортова реакція на фон мінерального живлення в залежності від строку сівби. Так, на фоні без добрив (контроль) по всіх строках сівби, окрім останнього, вищу урожайність отримано у сорту Романтика 1,70-1,77 т/га, а за посіву сої 21.05 - у сорту Аннушка - 1,58 т/га.
Аналогічна ситуація і в разі застосування в основне удобрення 30 т/га гною та $\mathrm{N}_{30} \mathrm{P}_{30} \mathrm{~K}_{30}$ на фоні гною - за перших трьох строків вищу продуктивність формував сорт Романтика від 1,82 до 1,91 т/га на першому та від 1,94 до 2,01 т/га на другому фоні. За четвертого та п'ятого строків сівби на фоні гною вищу продуктивність забезпечив сорт Аннушка - 1,82 та 1,76 т/га. На фоні гній $+\mathrm{N}_{30} \mathrm{P}_{30} \mathrm{~K}_{30}$ за четвертого строку вища урожайність отримана у сорту Аннушка - 1,78 т/га, а за п’ятого - у сорту Скеля - 1,83 т/га.

У разі вирощування сої на фоні $\mathrm{N}_{60} \mathrm{P}_{60} \mathrm{~K}_{60}$ та фоні оранки вищу урожайність по всіх строках сівби отримано під час вирощування сорту Аннушка - від 1,79 до 1,93 т/га. У випадку застосування під сою мінеральних добрив у дозі $\mathrm{N}_{60} \mathrm{P}_{60} \mathrm{~K}_{60}$ та чизельного обробітку грунту за першого строку сівби вищу урожайність отримано під час вирощування сортів сої Аннушка i Романтика - 1,87 та 1,88 т/га, за інших чотирьох - сорту Аннушка - рівень продуктивності від 1,72 до 1,93 т/га.

Аналізуючи результати досліджень впливу строків сівби на урожайність сортів сої по роках досліджень (2006-2010 рр.), необхідно зазначити наступне: на фоні без добрив в 2006 р. практично по всіх строках кращі результати отримано по сорту Романтика - від 1,23 до 1,48 т/га, крім того за четвертого та п'ятого строків досить високу продуктивність формували сорти Аннушка та Скеля по 1,34 т/га.

Сорт Аннушка кращі результати забезпечив у 2007 та 2010 роках; сорт Романтика - у 2006, 2008 та 2009 pр. По сорту Скеля результати, близькі до максимальних, отримані в 2009 році.

У випадку застосування під культуру 30 т/га гною спостерігається диференціація сортів по реакції на строк сівби. Так, за першого строку сорт 
Аннушка кращі результати забезпечив у 2006 та 2007, сорт Романтика - 2008 по 2010 pр. за другого - 2007 та 2010 pp. і 2006 та 2008 pp., а в 2009 сорт Скеля. Схожа ситуація і в разі вирощування сої на фоні гною 3 додатковим внесенням $\mathrm{N}_{30} \mathrm{P}_{30} \mathrm{~K}_{30}$ - в 2009 р. по всіх строках вищу продуктивність було отримано у сорту Скеля - від 2,44 до 2,53 т/га, сорт Аннушка беззаперечним лідером був у 2007 p., у 2006 р., залежно від строку вищі показники забезпечували сорти Аннушка та Романтика.

На фоні $\mathrm{N}_{60} \mathrm{P}_{60} \mathrm{~K}_{60}$ та оранки в більшості років досліджень кращі результати отримано під час вирощування сорту Аннушка, а сорту Романтика - лише у 2009 р. У разі застосування під сою чизельного обробітку грунту досить високі результати забезпечував сорт Скеля у 2007 р. за четвертого та п'ятого строків посіву, у 2008 - за 4-го, у 2009 р. - за всіх строків; сорт Романтика - у 2006 р. за 3-го строку, у 2008 та 2009 рр. - за першого. За всіх інших строків посіву в усі роки досліджень вищі результати отримано у випадку вирощування сорту Аннушка.

У період 2011-2013 рр. продовжували вивчення строків сівби сортів сої на рівень їх продуктивності. В середньому по фонах мінерального живлення вищий рівень урожайності отримано під час вирощування сорту Романтика, який становив відповідно строків 1,97, 2,15 та 2,14 т/га, близькі до нього показники забезпечив (1,91, 2,04 та 2,14 т/га) сорт Скеля. Аналогічна закономірність спостерігається і по фонах мінерального живлення (рис. 1).

Результати дослідів підтверджують можливість отримання стабільних врожаїв по роках за рахунок підбору строку сівби та фону мінерального живлення. Вони також свідчать про те, що основним фактором, який визначає рівень урожайності сої є погодні умови в критичні фази росту для конкретного сорту.

Так, для ультра ранньостиглого сорту Аннушка, в середньому за три роки, рівнозначними були ранній та пізній строки сівби, середній рівень врожайності по строках 1,70 т/га та 1,74 т/га. Для більш пізньостиглих сортів Романтика та Скеля - кращими виявилися другий та третій строки.

У разі застосування фонів мінерального живлення (30 т/га гною та мінеральних добрив на його фоні) рівень урожайності сорту Аннушка за першого та третього строків сівби був однаковим. Тобто, в разі застосування добрив - як органічних, так і мінеральних - вплив строку сівби на продуктивність даного сорту нівелюється.

Для сортів Романтика та Скеля більш ефективними були більш пізні строки сівби. Так, середня урожайність сорту Романтика за другого та третього строків становила відповідно 2,15 т/га та 2,14 т/га, проти 1,97 т/га за раннього. Для сорту Скеля значення цього показника становили відповідно строків сівби 2,04 т/га та 2,14 т/га проти 1,91 т/га.

Результати дослідів 2014-2015 рр. підтверджують дані попередніх років про можливість отримання стабільних врожаїв по роках за рахунок підбору строку сівби. Вони також свідчать про те, що основним фактором, який визначає рівень урожайності сої $є$ погодні умови в критичні фази росту для конкретного сорту.

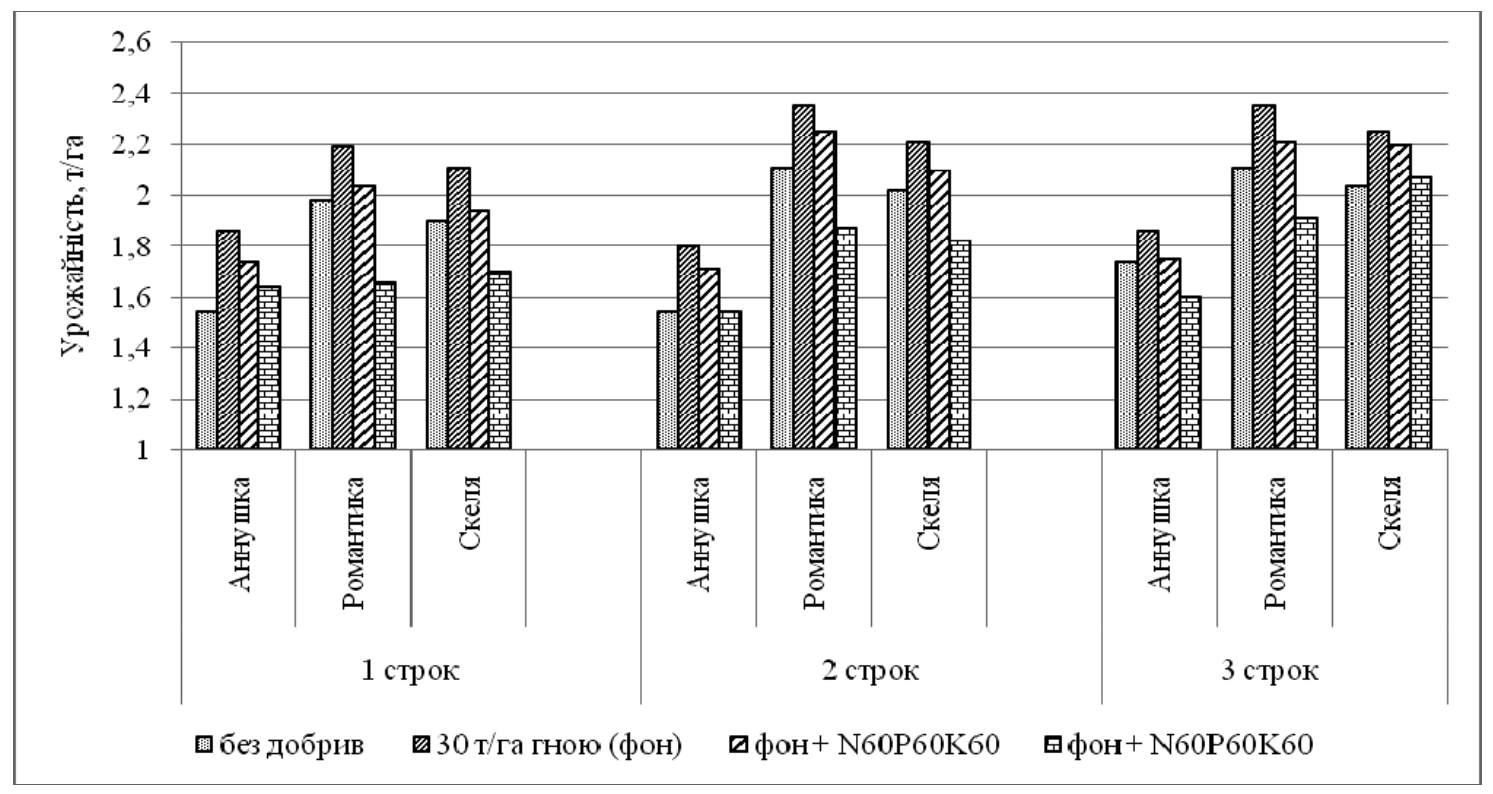

Рис. 1. Урожайність сортів сої в залежності від строків сівби в середньому за 2011-2013 pp., $\mathrm{m} / 2 a$ 


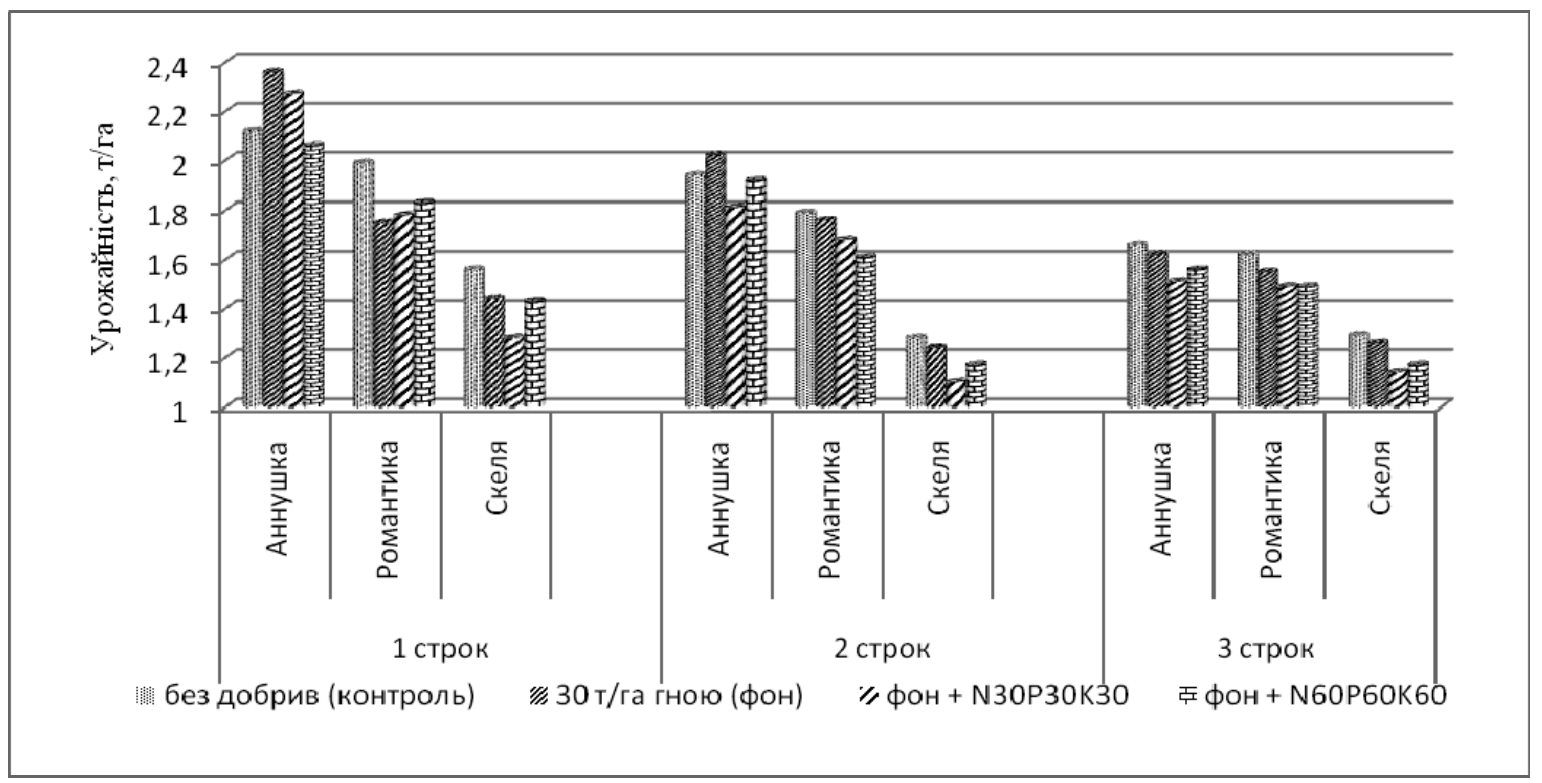

Рис. 2. Урожайність сортів сої в залежності від строків сівби в середньому за 2014-2015 pp., m/2а

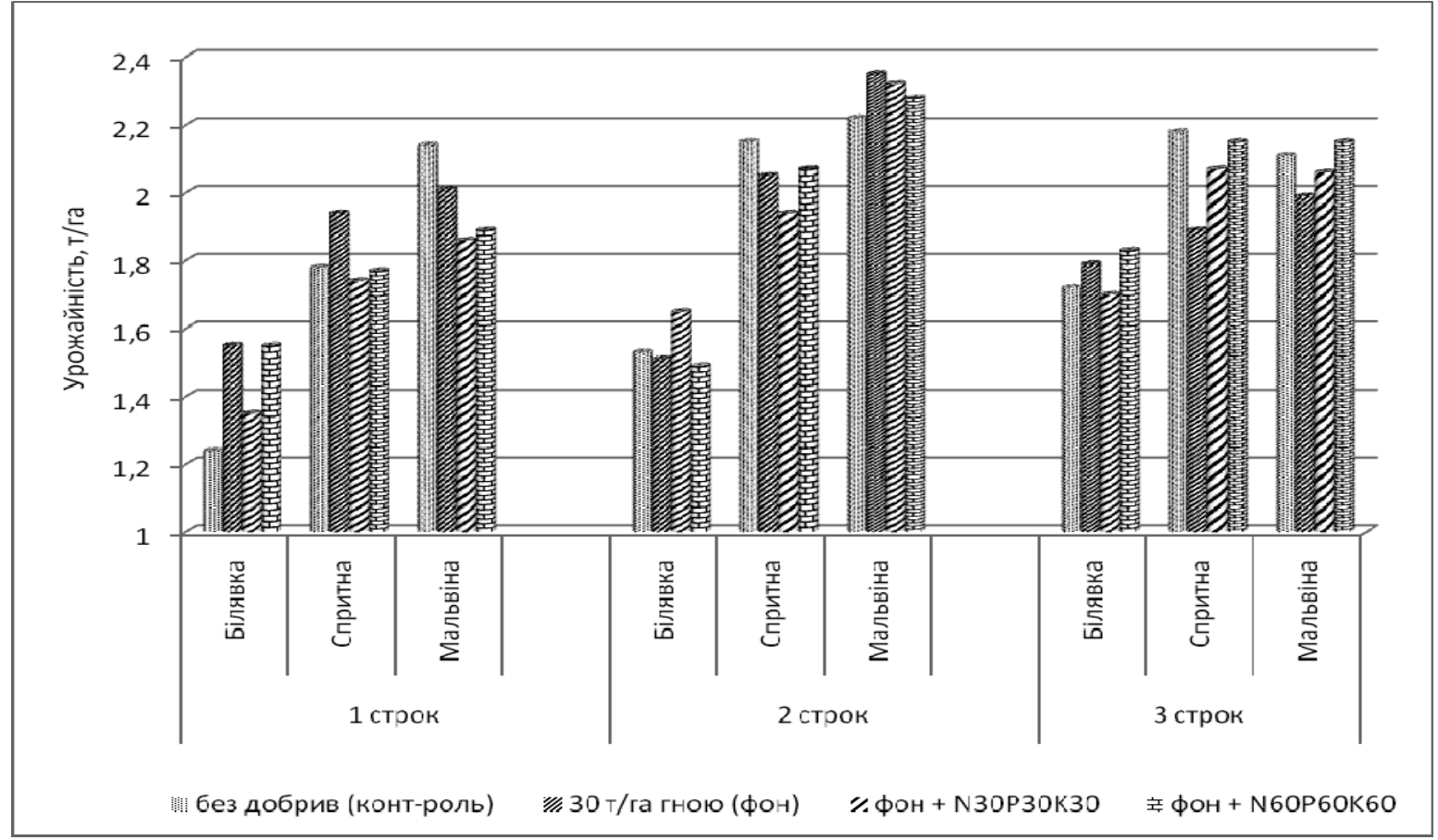

Рис. 3. Урожайність сортів сої в залежсності від строків сівби в середньому за 2016-2017 рр., m/2а

Застосування для сої раннього строку сівби в умовах 2014-2015 рр. було найбільш ефективним. Так, для ультраранньостиглого сорту Аннушка кращим був ранній строк сівби, середній рівень врожайності по строку - 2,14 т/га. Запізнення із сівбою призводило до зниження урожайності сорту, яка становила 1,89 т/га та 1,56 т/га відповідно строку сівби (рис. 2). Найнижча врожайність даного сорту як по фонах мінерального живлення, так і в середньому отримана за сівби на початку III декади травня.
Для сорту Романтика також вищий рівень урожайності отримано за раннього строку сівби 3 середнім рівнем продуктивності 1,80 т/га. За інших строків вона становила 1,69 т/га та 1,51 т/га 3 коливаннями залежно від фону мінерального живлення від 1,41 т/га до 1,99 т/га. Перенесення сівби на пізній строк значною мірою знижувало урожайність сорту на всіх фонах живлення.

Аналогічна ситуація щодо впливу строку сівби на урожайність спостерігалася і у сорту Скеля. Середня врожайність залежно від строку сів- 


\section{СІЛЬСЬКЕ ГОСПОДАРСТВО. РОСЛИННИЦТВО}

би становила $1,43,1,20$ та 1,21 т/га. Для отримання високого рівня урожайності необхідно проводити сівбу сої в кінці квітня місяця, що дасть можливість отримати урожайність в залежності від сорту на рівні 1,73-2,22 т/га.

За період 2016-2017 рр. також відмічалася сортова особливість у формуванні рівня урожайності сої залежно від строку сівби та фону мінерального живлення. Так, у сорту Білявка, за контрольного варіанту, вища урожайність отримана за пізнього строку сівби - 1,72 т/га. Використання більш ранньої сівби призводило до зниження даного показника, відповідно до 1,53 т/га за оптимального та 1,24 т/га за раннього строку (рис. 3).

Аналогічна закономірність і для сорту Спритна. Під час вирощування сорту Мальвіна, як більш пізньостиглого, вищий рівень продуктивності було сформовано за оптимального строку сівби (2,22 т/га) та зниження за інших: 2,14 т/газа раннього та 2,018 т/га - за пізнього. Відмічена також і різниця в рівні урожайності сортів сої залежно від фону мінерального живлення. Так, за раннього строку сівби вища урожайність сорту Білявка отримана на фонах 30 т/га гною та 30 т/га гною $+\mathrm{N}_{60} \mathrm{P}_{60} \mathrm{~K}_{60}-$ по 1,55 т/га, за оптимального - фон $+\mathrm{N}_{30} \mathrm{P}_{30} \mathrm{~K}_{30}-1,65$ т/га, а за пізнього строку - на фоні 30 т/га гною $+\mathrm{N}_{60} \mathrm{P}_{60} \mathrm{~K}_{60}-$ 1,83 т/га. У разі вирощування сорту Спритна 30 т/га гною $(2,14$ т/га), контроль $(2,15$ т/га) та 2,18 т/га і для сорту Мальвіна - контрольний варіант (2,14 т/га), 30 т/га гною (2,35 т/га) та 30 т/га гною $+\mathrm{N}_{60} \mathrm{P}_{60} \mathrm{~K}_{60}(2,15$ т/га) відповідно строків сівби.

Висновок. У середньому за роки досліджень відхилення по середньодобовій температурі становить плюс $1,3{ }^{\circ} \mathrm{C}$. У той же час існує значна різниця за місяцями і роками. Березень тепліший на $0,9^{\circ} \mathrm{C}$, а травень - на $0,5^{\circ} \mathrm{C}$. Сума ефективних температур за період досліджень становила $1496,8{ }^{\circ} \mathrm{C}$, що на $290,8{ }^{\circ} \mathrm{C}$, або $24,1 \%$ вище середнього багаторічного показника, а сума опадів, у порівнянні з багаторічними значеннями, зросла на 34,4 мм. Розрахунки лінійних регресій свідчать про постійне і стабільне підвищення середньодобових температур по всіх місяцях. При цьому воно незначне у квітні і різко підвищується в літні місяці, особливо в серпні. Відмічена різна реакція сортів сої на строки сівби. Результати дослідів підтверджують можливість отримання стабільних врожаїв по роках за рахунок

\section{БІБЛІОГРАФІЯ}

1. Бабич А. О. Проблема білка і вирощування зернобобових на корм / А. О. Бабич. - 3-е вид. підбору строку сівби та фону мінерального живлення у середньому за 2002-2005 pр. У сорту Романтика відмічена чітка тенденція збільшення врожайності від ранніх до пізніх строків незалежно від фонів живлення (від 1,73 т/га до 2,08 т/га в середньому за 4 роки). У сортів Мрія та Аметист на фоні без добрив проявляється така ж тенденція, тоді як на фоні застосування добрив найбільш оптимальними строками були більш ранні (III декада квітня і I декада травня), ніж пізні. Вищий рівень продуктивності сої за 20062010 рр. було отримано за раннього (22.04) строку сівби - 1,82 т/га, а найгірші показники отримано за пізньої (21.05) сівби, де врожайність була в межах 1,67 т/га. В розрізі сортів: кращі результати, за більшості строків, окрім пізніх було отримано у випадку вирощування сорту Романтика, який забезпечив отримання 1,84-1,87 т/га насіння. За пізніх строків - третій (06.05), четвертий (14.05) та п’ятий (21.05) вищий рівень продуктивності було отримано в разі вирощування сорту Аннушка - 1,72-1,85 т/га.

Для ультраранньостиглого сорту Аннушка в середньому за 2011-2013 pp. рівнозначними були ранній та пізній строки сівби, середній рівень врожайності по строках - 1,70 т/га та 1,74 т/га. Для більш пізньостиглих сортів Романтика та Скеля кращими виявилися другий та третій строки.

Застосування для сої раннього строку сівби в умовах 2014-2015 pр. було найбільш ефективним. Для ультраранньостиглого сорту Аннушка середній рівень врожайності по строку - 2,14 т/га, запізнення із посівом призводило до зниження врожайності до 1,89 т/га та 1,56 т/га відповідно строку сівби для сорту Романтика 1,80 т/га, 1,69 т/га та 1,51 т/га, сорту Скеля - 1,43, 1,20 та 1,21 т/га.

За 2016-2017 pp. вища урожайність сорту Білявка, за контрольного варіанту, отримана за пізнього строку сівби - 1,72 т/га. Використання більш ранньої сівби призводило до зниження даного показника до 1,53 т/га за оптимального та 1,24 т/га - за раннього строку. Аналогічна закономірність і для сорту Спритна. Під час вирощування сорту Мальвіна, як більш пізньостиглого, вищий рівень продуктивності було сформовано за оптимального строку сівби $(2,22$ т/га) та зниження за інших $-2,14$ т/га за раннього та 2,018 т/га - за пізнього строку сівби.

перероб. - К. : Урожай, 1993. - 192 с. 


\section{СІЛЬСЬКЕ ГОСПОДАРСТВО. РОСЛИННИЦТВО}

2. Макрушина 6 . Утилізація ліпідів при проростанні насіння кукурудзи та сої залежно від його морфологічної будови / Є. Макрушина // Вісн. Львів. ДАУ. - Агрономія. - Львів, 2001. №5. $-617 \mathrm{c}$.

3. Січкар В. I. Фізіологічна реакція сортів сої на посуху і підвищену температуру / В. І. Січкар, А. К. Ляшок, В. М. Мусич // Физиология и биохимия культурных растений. - 2001. - №6. C. 497-503.

4. Терентьев Ю. В. Технологические основы комплексной механизации производства сои / Ю. В. Терентьев. - Благовещенск : ВНИИ сои, 1988. - $97 \mathrm{c}$.

5. Бабич A. O. Соя для здоров'я і життя на планеті Земля = Soya for Healthand Life on Earth / А. O. Babich. - К. : Аграрна наука, 1998. - 271 c.

6. Петриченко В. Ф. Особливості формування продуктивності сої залежно від гідротермічних ресурсів та впливу агротехнічних заходів / В. Ф. Петриченко, Л. М. Середа // Зб. Наук. праць Вінницького державного сільськогосподарського інституту. - Вінниця. - 2000. - Випуск 8, T. 1.

7. Соя / [Прус А. В., Сичкарь В. И., Колот В. Н. и др.]. - К. : Урожай, 1982. - 78 с.

8. Селекция, семеноводство и технология возделывания сои : Сб. науч. тр. / Груз. НИИ земледелия им. Ю. Н. Ломоури; [Редкол. : М. Б. Гвинджилия (гл. ред.) и др.]. - Тбилиси : НИИ земледелия, 1983. $-216 \mathrm{c}$.

9. Соя: аспекты устойчивости, методы оценки и отбора / [Шерепитко В. В., Жакотэ А. Г., Павлова Л. С. и др.] ; Отв. ред. Н. Н. Балашова ; АН ССР Молдова, Ин-т экол. генетики. - Кишинев : Штиинца, 1990. - $176 \mathrm{c}$.

10. Петриченко В. Ф. Наукові основи сталого соєсіяння в Україні / В. Ф. Петриченко // Корми і кормовиробництво. - 2011. - Вип. 69. - С. 3-10.

11. Бабич А. О. Селекція і розміщення виробництва сої в Україні : монографія / А. О. Бабич, А. А. Бабич-Побережна. - К. : ФОП Данилюк В. Г., 2008. $-216 \mathrm{c}$.

12. Камінський В. Ф. Значення зернових бобових культур та напрямки інтенсифікації їх виробництва / В. Ф. Камінський, П. С. Вишнівський, С. П. Дворецька, А. В. Голодна // Селекція і насінництво. - Х., 2005. - Вип. 90. - С. 14-22.
13. Баранов В. Ф. Реакция различных сортов сои на загущение // Научно-техн. бюллетень ВНИИМК. - Краснодар, 1989. - Вып. 4. - С. 8-12.

14. Поздняков В. Г., Посыпанов Г. С. Современное состояние, проблемы возделывания и использования сои // Соя: Научно-производственный справочник. - М. : ЦНСХБ, 1998. C. 6-24.

15. Сичкарь В. И. Реакция различных сортов сои на длину дня / В. И. Сичкарь, А. И. Верещака, В. В. Хангильдин // Научно-технический бюллетень Всесоюзного селекционно-генетического института. - Одесса, 1981. - №2 (40). C. 41-43.

16. Бламук М. I. Технологічні аспекти підвищення продуктивності соєвого поля / М. І. Блащук, А. О. Бабич // Корми і кормовиробництво. 2003. - Вип. 51. - С. 100-102.

17. Byth D. E. Comparative photoperiodic responses for several sojabean varieties of tropicaland temperate origin / D. E. Byth // Aust. J. Agr. Res. - 1968. - №19. - P. 145-150.

18. Crisvell J. G. Variation insensitivity to photoperiod among early maturing soybeans trains / J. G. Crisvell, D. J. Hume // CropSci. - 1972 . V. 12. - №5. - P. 140-147.

19. Johnson H. W. Effects of photoperiod and time of planting on rates of development of the soybean in various stages of the lifecycle / H. W. Johnson, H.A. Borthwick, K. C. Leffel // Bot. Gaz. - 1960. - V. 122. - №2. - P. 270-278.

20. Polson D. E. Day-neytrality in soybeans / D. E. Polson // CropSci. - 1972. - V. 12. - №6. - P. 223229.

21. Бабич А. Розміщення посівів і технологія вирощування сої в Україні / А. Бабич, С. Колісник, А. Побережна, А. Нємцов // Пропозиція. 2002. - №5. - C. 38-40.

22. Шевніков М. Я. Застосування біологічних, хімічних та фізичних засобів у технологіях вирощування сої і кукурудзи / М. Я. Шевніков, О. О. Коблай. - Полтава, 2015. - 258 с.

23. Шевніков М. Я. Особливості розвитку сої залежно від строків сівби в умовах лівобережного Лісостепу України / М. Я. Шевніков, О. П. Галич, I. І. Лотиш // Вісник Полтавської державної аграрної академії. - 2015. - №4. C. 15-17. 